\title{
Dermatology Research and Therapy
}

CASE REPORT

\section{Cutis Laxa of the Face: A Case Report and Review of Literature}

\author{
Misani $M^{*}$ and de Fontaine $S$
}

Erasme University Hospital, Belgium

*Corresponding author: Dr. Marta Misani, Erasme University Hospital, Route de Lennik 808, 1070 Bruxelles, Belgium, Tel: +32-(0)-2-555-45-50, Fax: +32-(0)-2-555-45-96, E-mail: martamisani@gmail.com

\section{Summary}

Introduction: Cutis laxa is a rare condition characterized by excessive loose pendulous skin, associated to premature aging expression. Histologically, the condition is related to the loss of dermal elastic tissue.

The localized variant of acquired cutis laxa, developing without preceding lesions, is extremely rare, with only eight reports in published literature.

We report the case of a young man presenting lesions confined to the face, causing severe cosmetic and social problems, along with a review of the literature.

Case Report: A 37-year-old man came to our consultation with a severe wrinkled face, extending from the forehead to the neck, with long and distorted earlobes and an important blepharochalasis resulting in visual limitation. No other systemic disorders were observed.

The patient was submitted to several plastic surgery interventions for correction, with satisfactory results. The histological findings confirmed the diagnosis.

Conclusion: Acquired localized cutis laxa confined to the face is a rare condition with only few cases reported in literature. The treatment is surgical, and includes extended facelift, extended deep forehead lift, and blepharoplasties. We reviewed the literature and confirmed the therapeutical approach.

\section{Keywords}

Cutis laxa, Elastolysis, Elastin, Acquired cutis laxa, Localized cutis laxa

\section{Introduction}

Cutis laxa is a rare disorder of the connective tissue, characterized clinically by loose, pendulous and inelastic skin producing the appearance of premature aging. The histology is peculiar for loss of dermal elastic tissue.
It may be inherited or acquired, both forms being generalized or localized. The acquired localized form is very uncommon and is usually preceded by inflammatory lesions.

We report the ninth case of acquired localized cutis laxa confined to the face without preceding inflammatory lesions or associated diseases.

\section{Case Report}

We present the case of a 37-year-old man with progressive premature aging of the face which he noticed during the previous 10 years. He came to our attention asking for a facial rejuvenation and complaining of social life discomforts. He denied any inflammatory event, he had no history of drug allergy neither familiarity with this kind of pathology.

On physical examination the patient presented with a lax and deeply wrinkled face, from the forehead to the neck, pendulous earlobes and important blepharochalasis (Figure 1a, Figure $1 \mathrm{~b}$ and Figure $1 \mathrm{c}$ ).

The remainder of his skin appeared to be normal. Joints were not hyperextensible and apart from the cutaneous lesions the complete clinical examination was normal.

Laboratory tests, as well as chest $\mathrm{X}$ rays and electrocardiogram were normal. The findings were consistent with the diagnosis of cutis laxa.

The patient was submitted to several plastic surgery procedures, performed in two stages: An extended facelift and correction of earlobes with cutaneous plasties in a first time and a mask lift with blepharoplasties in a second surgery. 


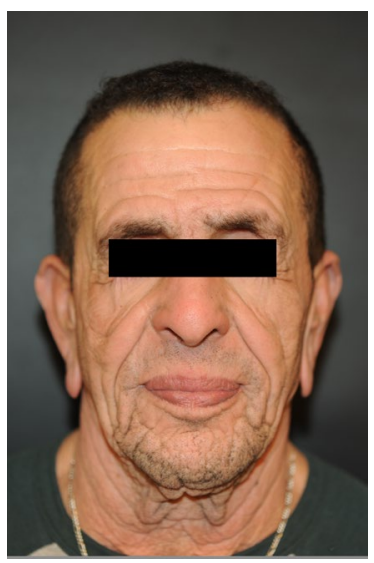

A

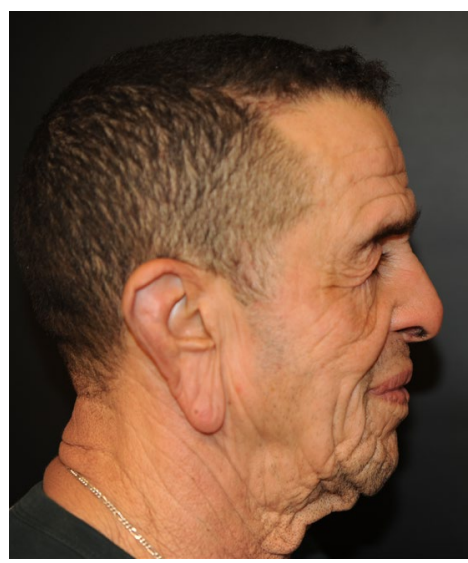

B

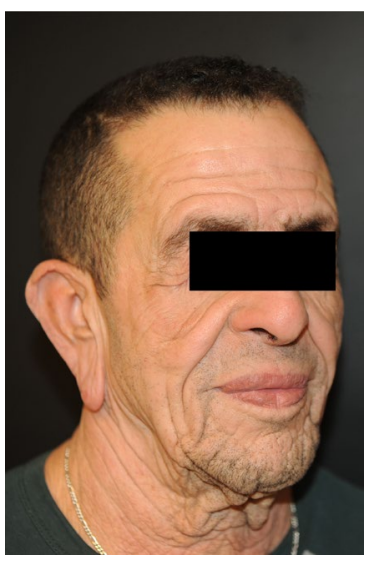

C

Figure 1: a,b,c) Lax and deeply wrinkled face, pendulous earlobes and blepharochalasis.

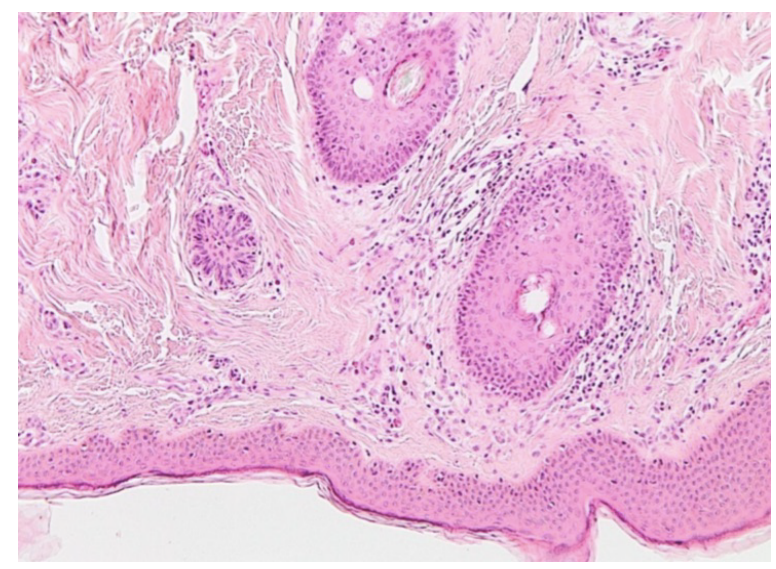

Figure 2: Hematoxyline/Eosine stain. Normal collagen fibers.

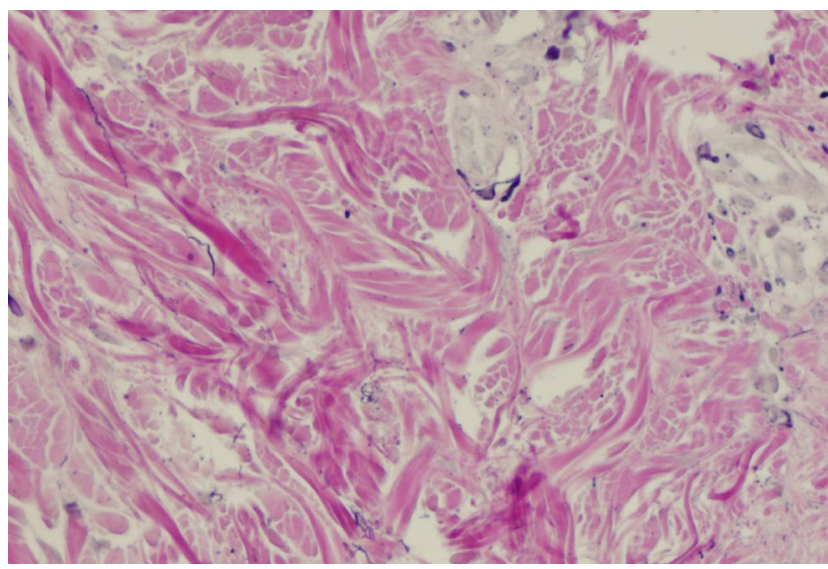

Figure 3: Orceine stain. Rarefaction of elastic fibers.

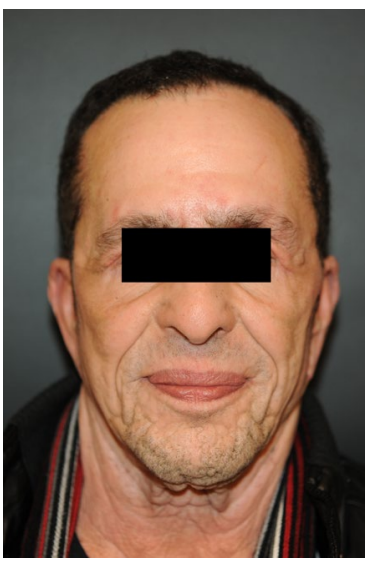

A

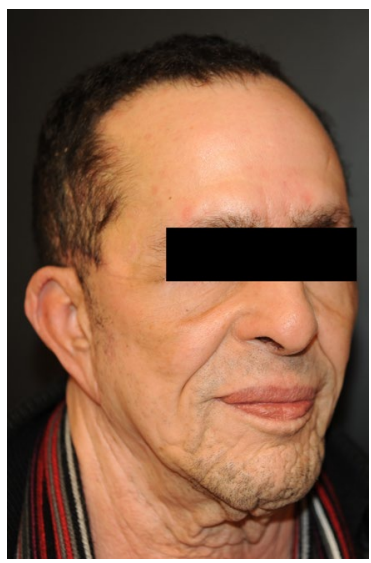

B

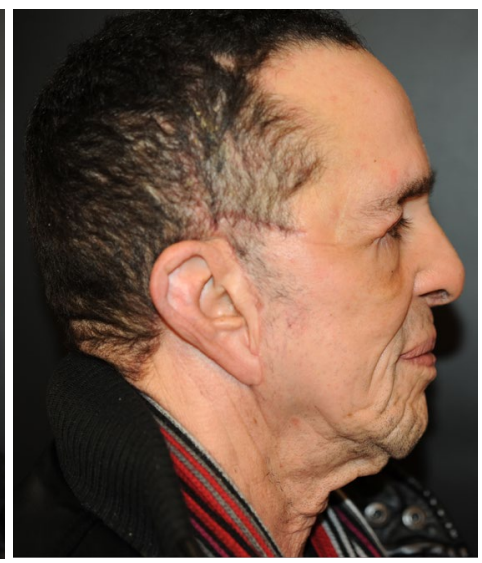

C

Figure 4: a,b,c) 3-month postoperatory results.

The skin biopsy confirmed the clinical diagnosis: Routine hematoxylin-eosin staining of the affected area revealed normal collagen fibers, without any inflammatory infiltrate. Orcein coloration, an elastic tissue stain, showed a marked reduction of elastic fibers in all layers of the dermis. Some remaining elastic fibers were fragmented and distorted (Figure 2 and Figure 3 ).

Three months after the second operation the patient was happy with surgery. We noticed good results at the forehead and the upper third of the face, but still some loose folds on the neck and under the chin, that could be submitted to a further surgery (Figure $4 a$, Figure $4 b$ and Figure 4c).

\section{Discussion}

Cutis laxa is a rare disorder of the connective tissue characterized by loose and pendulous skin and loss of elastic fibers. The term refers to a heterogeneous group 
of diseases with the same characteristic clinical presentation [1-3]. These conditions are distinguished in congenital or acquired, localized or generalized $[2,4]$.

The congenital form is more common, it can be inherited as autosomal recessive, autosomal dominant, and $\mathrm{x}$-linked disorder; it is associated with systemic diseases, which vary from severe cardiopulmonary disorders to mild affections.

Acquired cutis laxa is rare and it resembles the congenital disease from the clinical and histological point of view. It may be generalized or localized. Most of the cases reported in the literature refer to the generalized form (type I) which usually develop after inflammatory episodes, hypersensitivity reactions, neoplastic and hematologic disorders or in association with particular diseases [5-9].

Localized acquired cutis laxa is itself a rare variant with only few cases reported in literature. Most of the cases are preceded by inflammatory conditions or malignancies. Type II (Marshall's syndrome) has been described in African children and North Americans and is characterized by localized elastolysis following inflammatory skin conditions [4].

In review of the literature, few cases of localized acquired cutis laxa are described, but in the large majority the development of clinical manifestations was preceded by inflammatory lesions [5-9].
In eight cases the process was confined to the face and was not preceded by any inflammatory phase [1016]. The present patient would be the ninth case with such characteristics to date (Table 1 ).

As shown in the table, all the reported cases present facial localization, some confined to the eyelids and the others generalized, all with the same anatomical pattern. Date of onset and duration of the phenomenon is variable and there is no difference between genders.

The exact pathogenesis of acquired localized cutis laxa is unknown. Several hypotheses have been proposed including excessive elastase activity, dysfunction of elastase inhibitors with abnormal copper metabolism, deficiency of copper, decreased production of tropoelastin, and immune mediated mechanisms $[2,4]$.

The diagnosis is usually clinical, and the histopathological exam usually serves as a confirmation. The histopathological findings include significantly decreased elastic fibers, with residual elastic fibers being fragmented. Collagen is usually normal [17].

Routine laboratory tests are negative or normal. Serum elastase, serum elastase inhibitor, serum copper and ceruloplasmin, alpha1-antitrypsin and lysyl oxidase levels might be analysed, even though they are not required for the diagnosis. Systemic evaluation should be undertaken to investigate involvement of internal organs.

Table 1: Patient characteristics and details of reported cases of acquired localized cutis laxa.

\begin{tabular}{|c|c|c|c|c|c|c|c|c|c|c|}
\hline & Author & Year & Journal & Age & Sex & Duration & Localizaton & Histology & \begin{tabular}{|l|} 
Other \\
diseases
\end{tabular} & Treatment \\
\hline Pt 1 & $\begin{array}{l}\text { Barker, } \\
\text { et al. [10] }\end{array}$ & 1986 & $\begin{array}{l}\text { J Am } \\
\text { Acad Dermatol } \\
\text { 1986; 14: 145-147. }\end{array}$ & 29 & $F$ & 18 months & $\begin{array}{l}\text { Upper } \\
\text { eyelids }\end{array}$ & I & I & $\mathrm{N} / \mathrm{A}$ \\
\hline Pt 2 & $\begin{array}{l}\text { Barker, } \\
\text { et al. [10] }\end{array}$ & 1986 & $\begin{array}{l}\text { J Am } \\
\text { Acad Dermatol } \\
\text { 1986; 14: 145-147. }\end{array}$ & 15 & $F$ & $\mathrm{~N} / \mathrm{A}$ & I & I & I & N/A \\
\hline Pt 3 & $\begin{array}{l}\text { Greenbaum, } \\
\text { et al. [11] }\end{array}$ & 1989 & $\begin{array}{l}\text { Int J Dermatol } \\
\text { 1989; 28: 402-406. }\end{array}$ & 21 & $\mathrm{M}$ & 6 yrs & I & I & I & N/A \\
\hline Pt 4 & $\begin{array}{l}\text { Ghigliotti, } \\
\text { et al. [12] }\end{array}$ & 1991 & $\begin{array}{l}\text { J Am Acad } \\
\text { Dermatol 1991; } 24: \\
504-505 .\end{array}$ & 18 & $\mathrm{~F}$ & N/A & Face & VVG & I & N/A \\
\hline Pt 5 & $\begin{array}{l}\text { Riveros, et } \\
\text { al. [13] }\end{array}$ & 2004 & $\begin{array}{l}\text { Int J Dermatol } \\
\text { 2004; 43: 931-935. }\end{array}$ & 27 & $F$ & 5 yrs & Face & H\&E, VVG & I & $\begin{array}{l}\text { Rhytidectomy, } \\
\text { bilateral } \\
\text { blepharoplasty }\end{array}$ \\
\hline Pt 6 & $\begin{array}{l}\text { Ozsoy, et al. } \\
{[15]}\end{array}$ & 2007 & $\begin{array}{l}\text { Dermatol Surg } \\
2007 ; 33: 1510- \\
1512 .\end{array}$ & 20 & $\mathrm{~F}$ & 10 yrs & $\begin{array}{l}\text { Upper } \\
\text { eyelids }\end{array}$ & $\begin{array}{l}\text { H\&E } \\
\text { Orcein }\end{array}$ & I & $\begin{array}{l}\text { Upper } \\
\text { blepharoplasties }\end{array}$ \\
\hline Pt 7 & $\begin{array}{l}\text { Larangeira } \\
\text { de } \\
\text { Almeida, et } \\
\text { al. [16] }\end{array}$ & 2008 & $\begin{array}{l}\text { J Cutan Pathol } \\
\text { 2008; 35: 58-61. }\end{array}$ & 22 & $M$ & 4 yrs & Face & $\begin{array}{l}\mathrm{H} \& \mathrm{E}, \\
\text { VVG }\end{array}$ & I & $\begin{array}{l}\text { Face lift, } \\
\text { blepharoplasties, } \\
\text { correction of } \\
\text { earlobes }\end{array}$ \\
\hline Pt 8 & $\begin{array}{l}\text { Mehta, et al. } \\
{[14]}\end{array}$ & 2011 & $\begin{array}{l}\text { Pediatr Dermatol } \\
\text { 2011; 28: 421-423. }\end{array}$ & 16 & $M$ & 2 yrs & Face & H\&E, VVG & I & Rhytidectomy \\
\hline Pt 9 & $\begin{array}{l}\text { Current } \\
\text { Patient }\end{array}$ & 2014 & & 37 & $M$ & 10 yrs & Face, neck & $\begin{array}{l}\text { H\&E, } \\
\text { Orcein }\end{array}$ & I & $\begin{array}{l}\text { Face-lift, } \\
\text { frontal lifting, } \\
\text { blepharoplasty } \\
\text { and correction of } \\
\text { earlobes }\end{array}$ \\
\hline
\end{tabular}


No medical treatment is available for correction of the pathology of disease or to reduce its progression. Dapsone was given to patients with the inflammatory phase and was able to control swelling. However, it did not prevent progression of the disease [7-9].

Plastic surgery remains the only modality of treatment for correction to improve cosmetic appearance and social issues of the patient. Extended facelift, blepharoplasty, and ear lobe reduction may be performed, with obviously, a larger amount of skin excess to remove. Furthermore, these patients should be informed that repeating operations may be necessary $[18,19]$.

However, in literature there are few reports focusing on plastic surgery procedures, results and the need of further surgeries $[19,20]$. Our follow up covers only a 3-month period, and the patient is now happy with the results.

From a critical point of view, we noticed that the correction was not optimal in the neck and submental area, and we have recommended further surgery focused on that area. Our follow up is short, and the patient will probably have to undergo further surgeries: However, there are no reports in literature focusing on the longterm aesthetic results in acquired localized cutis laxa.

\section{Acknowledgements}

We would like to thank Dr. Ursula Sass and Dr. Trépant for their kindness and patience while explaining the histological examinations.

\section{Conflict of Interest Statement}

All authors disclose any financial and personal conflict of interest and any funding source in this paper.

\section{References}

1. Burrows NP, Lovell CR (2004) Disorders of elastic fibres. In: Burns T, Breathnach SM, Cox N, Griffiths C, Rook's textbook of dermatology. ( $7^{\text {th }}$ edn), Blackwell Science Ltd., Malden, USA, 18-19.

2. Brown FR 3rd, Holbrook KA, Byers PH, Stewart D, Dean J, et al. (1982) Cutis laxa. Johns Hopkins Med J 150: 148153.

3. Harris RB, Heaphy MR, Perry HO (1978) Generalized elastolysis (cutis laxa). Am J Med 65: 815-822.

4. Reed WB, Horowitz RE, Beighton P (1971) Acquired cutis laxa. Primary generalized elastolysis. Arch Dermatol 103: 661-669.
5. Yoneda K, Kanoh T, Nomura S, Ozaki M, Imamura S (1990) Elastolytic cutaneous lesions in myeloma-associated amyloidosis. Arch Dermatol 126: 657-660.

6. Machet MC, Machet L, Vaillant L, Estève E, de Muret A, et al. (1995) Acquired localized cutis laxa due to cutaneous lymphoplasmacytoid lymphoma. Arch Dermatol 131: 110111.

7. Kerl H, Burg G, Hashimoto K (1983) Fatal, penicillin-induced, generalized post-inflammatory elastolysis (cutis laxa). Am J Dermatopathol 5: 267-276.

8. Choy SY, Maguire RF (1980) Multiple myeloma associated with acquired cutis laxa. Cutis 26: 209-211.

9. Lewis FM, Lewis Jones S, Gipson M (1993) Acquired cutis laxa with dermatitis herpetiformis and sarcoidosis. J Am Acad Dermatol 25: 846-848.

10. Barker SM, Dicken CH (1986) Elastolysis of the earlobes. J Am Acad Dermatol 14: 145-147.

11. Greenbaum SS, Krull EA, Rubin MG, Lee R (1989) Localized acquired cutis laxa in one of identical twins. Int J Dermatol 28: 402-406.

12. Ghigliotti G, Parodi A, Borgiani L, Gambini C, Rebora A (1991) Acquired cutis laxa confined to the face. J Am Acad Dermatol 24: 504-505.

13. Riveros CJ, Gavilan MF, Franca LF, Sotto MN, Takahashi MD (2004) Acquired localized cutis laxa confined to the face: Case report and review of the literature. Int J Dermatol 43: 931-935.

14. Mehta B, Amladi S (2011) Acquired localized cutis laxa of the face: A rare presentation. Pediatr Dermatol 28: 421423.

15. Ozsoy Z, Gozu A, Dayicioglu D, Mete O, Buyukbabani N (2007) Localized cutis laxa and blepharoplasty. Dermatol Surg 33: 1510-1512.

16. de Almeida HL Jr, Wolter M, de Farias MV, de Castro LA (2008) Elastic tissue damage in cephalic acquired cutis laxa. J Cutan Pathol 35: 58-61.

17. Nanko H, Jepsen LV, Zachariae H, Søgaard H (1979) Acquired cutis laxa (generalized elastolysis): Light and electron microscopic studies. Acta Derm Venereol 59: 315324.

18. Nahas FX, Sterman S, Gemperli R, Ferreira MC (1999) The role of plastic surgery in congenital cutis laxa: a 10-year follow-up. Plast Reconstr Surg 104: 1174-1178.

19. Duperrat B, Dufourmentel Cl, Lorenceau B (1977) Cutis laxa et anedotermie. Ann Chir Plast.

20. Banks ND, Redett RJ, Mofid MZ, Manson PN (2003) Cutis laxa: Clinical experience and outcomes. Plast Reconstr Surg 111: 2434-2442. 